\title{
Engaging Youth Through Youth-Adult Partnerships (Y-AP): Implications for Education and Community Organizations
}

\author{
Steven Eric Krauss \\ ${ }^{a}$ Universiti Putra Malaysia 43400 Serdang, Selangor \\ Corresponding e-mail lateef@upm.edu.my
}

\begin{abstract}
In educational settings the world over, youth are increasingly disengaged from schools and communities. Increased dropout rates, truancy, crime, and general malaise within schools and youth programs indicate a disengagement problem in the context of youth learning spaces. Creating learning settings where young people feel valued, have a sense purpose, and find relevance to personal goals and futures, remains a challenge. In this presentation, I present the concept of youthadult partnership (Y-AP) as a promising strategy for addressing the challenge of youth engagement. $\mathrm{Y}-\mathrm{AP}$ is based on the premise that adult-supported youth voice on issues that affect young people will result in greater perceived value in education, and consequently, greater investment in learning by students. Drawing mostly on research from youth development organizations and afterschool programs that report high youth motivation and empowerment among young people, educators have begun to turn to similar strategies. Opportunities for voice in shaping curriculum, coconstructing assignments, and immersion in consequential activities, are found to promote student engagement. Students and youth who express voice on issues that affect them (i.e., school schedule, choice of classes, learning modality, program decision-making) are more likely to see value in their education, and consequently, become more invested in their learning. Case studies from Nigeria and Malaysia are presented to showcase how Y-AP can bring adults and youth together on issues of mutual concern, and create more engaging developmental settings for young people. The presentation concludes with four strategies for implementing Y-AP in organizations.
\end{abstract}

Keywords: Youth-adult partnership; youth engagement; community organizations; youth programs

\section{YOUTH DISENGAGEMENT: A GROWING CONCERN}

To grow up healthy, young people require a plethora of learning experiences that are motivating, relevant, provide them with opportunities to make decisions, and are carried out in the context of supportive relationships with others (Lerner, 2005). Such learning contexts - whether based in families, schools or communities - are effective when there is engagement between the young person and his or her environment (Li \& Jullian, 2012). Research from multiple countries indicates that many youth, however, are increasingly disengaged from these proximal developmental settings. In the case of schooling, it is well known that students thrive when emotionally connected and cognitively engaged (Finn \& Rock, 1997; Wang \& Eccles, 2013; Wang \& Holcombe, 2010). Schools across the world face challenges to engage students, however. Research estimates that a significant percentage of students are either disengaged in classrooms or not completing school, making engagement a salient global issue (UNESCO, 2016).

\section{ENGAGING YOUTH THROUGH YOUTH-ADULT PARTNERSHIP (Y-AP)}

Youth-adult partnership works along the lines of youth voice in decision-making and caring relationships with adults who recognize the value in helping youth exercise voice (Serido, Borden \& Perkins, 2011; Zeldin, Christens \& Powers, 2013). Y-AP takes many forms including youth and adults sitting on organizational governance committees, 
administering community projects together, making joint decisions about school policies, adult support of youth association activities, and joint advocacy efforts on behalf of communities. Across these different forms, however, is that Y-AP promotes many of the experiences that are engaging to young people: authentic decision making, reciprocity in learning, adults as natural mentors, and community connections. With the two components of youth voice and adult support, youth and adults collaborate as intergenerational partners, with interactions grounded in the principles of reciprocity, co-learning and shared control (Camino, 2005). Whether in school, community programs, or other types of organizations, youth-adult partnership emphasizes guided and supported youth participation as a way to help youth realize their rights and roles as citizens, and promotes personal development through the process of attaining substantive knowledge and practical skills via experiential learning from experienced adult partners (Checkoway, 2011).

\section{OUTCOMES OF Y-AP: WHAT THE RESEARCH TELLS US}

Moving beyond theory, it is important to look at how Y-AP has performed in different settings. Research on Y-AP has increased significantly in recent years, as more program and policy makers realize the need to make their youth-serving organizations more engaging and relevant to young people. Although much of the current research remains qualitative in nature, researchers are have recently begun to conduct survey research on Y-AP.

In the context of schools, mostly case study findings on Y-AP have been shown to contribute to school engagement, school attachment and civic engagement, outcomes strongly related to academic achievement (Mitra, 2009). Youth participation in school decision making increases student voice in schools and offers a way to re-engage students who may be disengaged from the school community (Fielding, 2001; Levin, 2000). Young people can engage with teachers in initiatives either inside or outside of the classroom to do this, such as working together to address student apathy with academic subjects or coming together to agree on ground rules for the school. Participation also can increase youth attachment to schools, which in turn has been shown to correlate with improved academic outcomes (Mitra, 2004).

When youth-adult partnership is used to engage young people in community projects, civic development increases, extending young people's beliefs that they can make a difference in their lives and the lives of others (Eccles \& Gootman, 2002;
Kirshner, Strobel \& Fernandez, 2003). Youth voice initiatives also help young people to develop important civic competencies including greater tolerance for, and relationships with others, respectfully and effectively questioning authority, and engaging in public speaking (Mitra, 2009). When young people are given opportunities to express voice and perceive adults as supportive, they are more likely to feel engaged, in addition to reporting a greater degree of community attachment and belonging (Krauss et al., 2017).

\section{LESSONS FROM THE FIELD}

Examples of effective Y-AP are growing. For our purposes, we highlight two unique programs that have made Y-AP a central component to their practice.

School-Based Management Committees, Nigeria (Umar et al., 2017). The School-based Management Committee (SBMC) is a form of decentralization of authority whereby decisionmaking and responsibility for school matters are transferred from higher authority to principals, teachers, parents, students and other members of the community the school is located (Caldwell, 2005; UNICEF/FME, 2012). The approach alters the bureaucratic style of school administration with a more democratic structure that brings about a bottom-up approach into educational planning and management (Gamage \& Zajda, 2005). In Nigeria, SBMC was implemented more than a decade ago with the aim of providing an opportunity for all stakeholders, particularly vulnerable groups such as young people and women, who do not usually have a strong voice in community affairs, to partake in school governance. Within the context of the SBMC, adults and youth assist one another in planning and management of the respective school and act as a conduit to the local community where the school is located (UNICEF/FME, 2012).

Umar et al. (2017) reported that successful SBMC's support youth committee members in expressing their voice through participation in a number of committees' activities. Specifically, youth participate in decision-making during meetings, construction of committee projects, administrative/managerial functions and monitoring of the committee's projects. They are also involved in revenue generation, planning, school visit and supervision, advocacy, and local campaigns.

Youth and Sports Association of Gaya Island, Sabah, Malaysia (Krauss, Dahalan \& Zeldin, 2015). Gaya Island is home to 10,000 low-income residents of traditional fishing villages that span the coast of the eastern and southern shores of the Island. 
BESUGA (Gaya Island Youth and Sports Association), the Island's lone youth association, used a Y-AP approach to bring positive social change to the Gaya Island community. Through the provision of community programs, the Association leaders worked closely with the adult residents in the villages to provide youth development and community education programs to youth and adult residents. These included sports tournaments, cultural events, community education programs (e.g., environmental awareness, education) and classes in sewing, computers, languages and others. This function was critical for building community relationships, social capital, and enhancing the skills of the population.

Second was the use of youth-adult partnership as an organizing tool to bring together a diverse group of stakeholders to lobby the government for water and electricity. In so doing, BESUGA was able to enlist support from local university leaders, the state electric company officials, community leaders, and state representatives. Taking advantage of a favorable political climate, the coalition of youth and adults succeeded in convincing the political leaders that Gaya Island was deserving of basic water and electricity infrastructures.

Third was BESUGA's role as a community educator. After approval was given to install electricity and water, BESUGA youth worked with local adults to devise strategies for educating the community about their new services. This required working with the state electric company, the village leaders (ketua kampong) and the adult residents. It also required a youth-led door-to-door effort to walk residents through the new processes of installation, payment and service of the electric and water utilities. The mass effort to educate the community could only be successful through cooperation between the youth and adults. Through these three initiatives, BESUGA showed how youth-adult partnership can provide a platform for youth to play substantive leadership roles in community development and transformation efforts.

\section{THE WAY FORWARD: TRANSFORMING ORGANIZATIONS WITH YOUTH, FOR YOUTH}

Reverse mentoring, shared ownership for learning, co-constructing curricula and assignments, joint advocacy campaigns on issues of importance to both youth and adults, youth advisory councils, these are just some of the ways that young people can partner with adults in youth-serving organizations. Youthadult partnership is a concept and a practice, but it is not a cookbook. There is no one way to do it, nor will it look the same in all cases. Young people can partner with adults in governance, training, advocacy, marketing and promotion - anywhere where they can make decisions and work alongside adults.

Shared wisdom from practitioners indicates that organizations must decide for themselves how, when and where young people will be involved in the work of the organization or program. The roles that adults will play in the process must also be considered. These decisions are best made explicitly, and should be driven by the leadership of the organization or program. If adults, especially, are not 'bought in' to the idea of Y-AP, it is unlikely to succeed. Organizations should also seek the assistance of capacity-builders, such as universities, to help them learn from the mistakes and successes of others, and to provide training and technical assistance on how to transition to a more youth and partnership-friendly setting.

\section{REFERENCES}

Caldwell, L. L. (2005). Recreation and youth development. Recreation and youth development, pp. 169-189.

Camino, L. (2005). Pitfalls and promising practices of youth-adult partnerships: An evaluator's

reflections. Journal of Community Psychology, 33, pp. 75-85.

Checkoway, B. (2011). What is youth participation?. Children and Youth Services Review, 33(2), pp. 340-345.

Eccles, J. \& Gootman, J. A., (Eds.). (2002). Community programs to promote youth development. National Academies Press.

Fielding, M. (2001). Students as radical agents of change. Journal of Educational Change, 2(2), pp. 123-141.

Finn, J. D., \& Rock, D. A. (1997). Academic success among students at risk for school failure. The Journal of Applied Psychology, 82(2), pp. 221-234.

Gamage, D., \& Zajda, J. (2005). Decentralization and school-based management: A comparative study of self-governing schools models. Educational Practice and Theory, 27(2), pp. 35-58.

Kirshner, B., Strobel, K., \& Fernández, M. (2003). Critical civic engagement among urban youth. Penn GSE Perspectives on Urban Education, 2(1), pp. 1-20.

Krauss, S. E., Kornbluh, M., \& Zeldin, S. (2017). Community predictors of school engagement: The role of families and youth-adult partnership in Malaysia. Children and Youth Services Review, 73, pp. 328-337.

Krauss, S.E., Zeldin, S., \& Dahalan, D. (2015). Traditional youth associations as agents of social change: A 
case study of youth and adult partnership in a Malaysian fishing village. Journal of Applied Youth Studies, 1(1), pp. 52-81.

Lerner, R. M. (2005). Promoting positive youth development: Theoretical and empirical bases. In White paper prepared for the workshop on the science of adolescent health and development, national research council/institute of medicine. Washington, DC: National Academies of Science.

Levin, B. (2000). Putting students at the centre in education reform. Journal of Educational Change, 1(2), pp. 155-172.

Li, J., \& Jullian,M. (2012). Developmental relationships as the active ingredient: A unifying working hypothesis of "what works" across intervention settings. American Journal of Orthopsychiatry, 82(2), pp. $157-186$.

Mitra, D. L. (2009). Collaborating with students: Building youth-adult partnerships in schools. American Journal of Education, 115(3), pp. 407-436.

Serido, J., Borden, L. M., \& Perkins, D. F. (2011). Moving beyond youth voice. Youth \& Society, 43(1), pp. 4463.

Wang, M. -T., \& Eccles, J. S. (2013). School context, achievement motivation, and academic engagement: A longitudinal study of school engagement using a multidimensional perspective. Learning and Instruction, 28, pp. 12-23.

Wang,M. -T., \& Holcombe, R. (2010). Adolescents' perceptions of school environment, engagement, and academic achievement in middle school. American Educational Research Journal, 47(3), pp. 633-662.

Umar, B. B., Krauss, S. E., Samah, A. A., \& Hamid, J. A. (2017). Youth voice in Nigerian school-based management committees. International Journal of Education \& Literacy Studies, 5(1).

UNESCO (2016). Global education monitoring report. Retrieved from: http://unesdoc. unesco.org/images/0024/002457/245752e.pdf

UNICEF/FME. (2012). Trainee's manual for training of school-based management committees on whole school development project. Abuja: Federal Ministry of Education.

Zeldin, S., Christens, B. D., \& Powers, J. L. (2013). The psychology and practice of youth-adult partnership: Bridging generations for youth development and community change. American Journal of Community Psychology, 51(3-4), pp. 385-397. 